\title{
Strategi Manajemen Pelatihan dan Pengembangan serta Pribadi Tenaga Pendidik dan Kependidikan
}

\author{
M. Angga Supratman', Gatot Sujono ${ }^{2}$, Fadly Usman ${ }^{3}$
}

Institut Pesantren K.H. Abdul Chalim

e-mail: anggasupratman@yahoo.com, cak_gatot@yahoo.com, fadlypwk@ub.ac.id

\begin{abstract}
International School Of Taraf International Amanatul Ummah is one of the schools that continues to produce quality students as evidenced by their achievements in both academic and non-academic fields. Therefore, the purpose of this study is to analyze: Strategies, results, and factors supporting and inhibiting training and development management as well as the personality of educators and education personnel. This research is a field research with a qualitative approach, from the informants of the School Coordinator, Educators and Education and Students. The results showed that 1) Management training and development through the following stages: Planning, namely a School Idiom, participatory management, formation of subject teacher deliberations, internal-external training. The implementation process, through needs assessment, provides encouragement and confidence, conditions the learning environment, ensures training implementation, selects training methods, evaluates training programs. The result, through transfers of knowledge, is accomplished. Factors. Supporters; personal teachers, institutions. Blocker; teacher teaching time, teacher vacation time. Meanwhile, 2) personal management of teachers through the following stages: Planning, from the Coordinating School of International Taraf, namely annual meeting discussions, teacher selection materials, creating a culture of partnership, building a climate. As for the teacher through the institutional environment, motivation from outside. The implementation steps, from the coordinator of the International Bertaraf School, namely selecting personal teachers, holding seminars, meeting regulations, building self-confidence, establishing communication, starting from oneself, respecting time, having a social spirit. As for the teacher, namely understanding competence, maintaining dignity, instructive reprimand, students a source of inspiration, wisely admonishing coworkers, giving encouragement $\mathcal{E}$ help, establishing good relationships with superiors, self-reflection. Factors. Supporters; environment, peer teachers, motivation. Blocker; genetic factors, saturation factors. Result. International Traffic School teachers, Amanatul Ummah, in their competence have been very helpful in terms of learning and as a good role model.
\end{abstract}

Keywords. HR Management; Training and Development and Teacher Personal

Abstrak. MBI Amanatul Ummah salah satu madrasah yang terus melahirkan siswasiswi yang berkualitas dibuktikan dengan capaian mereka dibidang akademik maupun non-akademik. Oleh karena itu, tujuan penelitian ini untuk menganalisis: Strategi, hasil, dan faktor pendukung dan penghambat manajemen pelatihan dan pengembangan serta pribadi tenaga pendidik dan kependidikan. Penelitian ini merupakan penelitian lapangan dengan pendekatan kualitatif, dari sumber informan Koordinator Madrasah, Pendidik dan Kependidikan serta Siswa. Hasil penelitian menunjukkan, bahwa 1) Manajemen pelatihan dan pengembangan melalui tahapan: Perencanaan, yakni sebuah Idiom Madrasah, manajemen partisipatoris, pembentukkan MGMP, pelatihan internaleksternal. Proses pelaksanaan, melalui penilaian kebutuhan, memberikan dorongan semangat dan keyakinan, mengkondisikan lingkungan pembelajaran, memastikan 
pelaksanaan pelatihan, memilih metode pelatihan, mengevaluasi program pelatihan. Hasil, melalui transfers of knowledge, prestasi. Faktor-faktor. Pendukung; pribadi guru, lembaga. Penghambat; waktu mengajar guru, waktu libur guru. Sedangkan 2) Manajemen pribadi guru melalui tahapan: Perencanaan, dari Koordiantor MBI yakni pembahasan raker tahunan, materi seleksi guru, menciptakan budaya partnership, membangun iklim. Adapun dari Guru melalui lingkungan lembaga, motivasi dari luar. Langkah-langkah pelaksanaan, dari Koordinator MBI yakni menyeleksi pribadi guru, mengadakan seminar, peraturan rapat, membangun rasa percaya diri, menjalin komunikasi, memulai dari diri sendiri, menghargai waktu, berjiwa sosial. Adapun dari Guru yakni memahami kompetensi, menjaga wibawa, teguran instruktif, siswa sumber inspirasi, bijak menegur teman kerja, memberi dorongan \& pertolongan, menjalin hubungan baik kepada atasan, intropeksi diri. Faktor-faktor. Pendukung; lingkungan, rekan guru, motivasi. Penghambat; faktor genetik, faktor jenuh. Hasil. Guru MBI Amanatul Ummah dalam kompetensinya sudah sangat membantu dalam hal belajar dan sebagai teladan yang baik.

Kata Kunci. Manajemen SDM; Pelatihan dan Pengembangan dan Pribadi Guru

Copyright (C JMPI: Jurnal Manajemen Pendidikan Islam. All Right Reserved.

This is an open access article under the CC BY-NC-ND license

(http://creativecommons.org/licenses/by-nc-nd/4.0/).

\section{A. PENDAHULUAN}

Mutu pendidikan di Indonesia hanya menempati peringkat ke-10 dari 14 negara berkembang. Sedangkan kualitas guru sebagai komponen penting dalam pendidikan tergolong memprihatinkan, berada di urutan ke-11 dari 14 negara berkembang di dunia (Yunus, 2020). Dalam perspektif mikro atau tinjauan secara sempit dan khusus, faktor dominan yang berpengaruh dan berkontribusi besar terhadap mutu pendidikan ialah guru profesional. Oleh karena itu, guru sebagai suatu profesi harus profesional dalam melaksanakan berbagai tugas pendidikan dan pengajaran, pembimbingan dan pelatihan yang diamanahkan kepadanya (Kartiko, 2019).

Semua organisasi baik organisasi publik maupun organisasi swasta memahami pentingnya mutu. Hal ini dapat dilihat dalam mencari sumber daya manusia (SDM) yang baik guna mendukung visi dan misi organisasi tersebut. Dalam suatu lembaga pendidikan pasti menginginkan sumber daya yang berkualitas agar dapat menghasilkan lulusan yang unggul. Dalam dunia pendidikan konsep mutu berkaitan dengan kompentensi guru, nilai-nilai moral yang dijunjung tinggi, dukungan dari masyarakat dan orang tua siswa, sumber yang memadai, didukung teknologi yang terkini, dipimpin oleh kepala sekolah yang kuat dan visioner, dan sangat memerhatikan kebutuhan peserta didik.

Implikasi pentingnya mutu ini membawa pengaruh pada praktik manajemen yang menghasilkan konsep manajamen mutu, yang berusaha meningkatkan kinerja, produktivitas, dan efisiensi. Hal ini hendaknya menjadi agenda lembaga untuk meningkatkan kualitas Pendidikan (Kartiko, 2019).

Di tengah berbagai persoalan Manajemen Sumber Daya Manusia yang berkembang di sekolah, MBI Amanatul Ummah sebagai salah satu madrasah yang tetap berdiri kokoh dengan kualitas lulusan dan prestasi-prestasi yang sudah terbukti, baik di taraf nasional maupun internasional. Sekolah ini memadukan dengan baik 
antara materi ilmu Agama dan ilmu Umum, sehingga lulusan madrasah ini selain berkemampuan tinggi di bidang ilmu umumnya juga mendalam akan pemahaman agamanya.

Berdasarkan hal tersebut tujuan penelitian ini adalah "untuk menganalisis strategi, hasil, dan faktor yang menjadi pendukung dan penghambat manajemen pelatihan dan pengembangan serta pribadi tenaga pendidik dan kependidikan". Sehigga hasil penelitian ini diharapkan dapat menyumbangkan suatu metode baru strategi MSDM, khususnya di MBI Amanatul Ummah Pacet, Mojokerto. Begitupun bagi dunia pendidikan pada umumnya. Sedangkan bagi kepala sekolah dan seluruh pengelola sekolah, diharapkan menjadi pertimbangan untuk pengembangan sumber daya manusia untuk kemajuan sekolah tersebut. Bagi peneliti lebih lanjut, agar dapat mengembangkan penelitiannya tentang manajemen SDM dalam perspektif yang berbeda. Sehingga, terdapat berbagai pengkayaan wacana sekaligus hasil temuan di lapangan yang mampu membangun sebuah teori baru.

\section{B. METODE}

Jenis penelitian ini termasuk penelitian lapangan (field research) yaitu data akan diperoleh dari hasil penelitian secara langsung di MBI Amanatul Ummah Pacet, Mojokerto. Sedangkan dari sifat data yang diperoleh, penelitian ini merupakan penelitian bersifat kualitatif. Dalam penelitian kualitatif, data yang diperoleh bersifat deskriptif yaitu berupa deskripsi kata-kata atau kalimat yang mengarah pada tujuan penelitian seperti tertuang pada fokus penelitian yang telah ditetapkan (Tanzeh, 2011). Untuk dapat memilih dan menilai data-data yang dibutuhkan sehingga mutlak kehadiran peneliti untuk berkomunikasi langsung dengan informan di lapangan yakni Koordiantor Madrasah, Tenaga Pendidik dan Kependidikan, serta Siswa yang berada di lingkungan MBI Amanatul Ummah Pacet Mojokerto.

Data yang dikumpulkan dalam penelitian ini adalah data dari wawancara dan observasi sebagai data utama, sementara itu dokumen merupakan data tambahan. Bila dilihat dari sumber datanya, maka pengumpulan data dapat menggunakan sumber primer dan sumber sekunder. Catherine Marshall, Gretchen B. Rossman didalm bukunya Sugiyono menyatakan bahwa "the fundamental methods relied on by qualitative researchers for gatherig information are, participation in the setting, direct observation, in-dept interviewing, document review" (Sugiyono, 2011).

Untuk menganalisa data yang sudah terkumpul peneliti menggunakan analisa secara deskriptif kualitatif yaitu menggambarkan, dan menganalisis semua hasil olah data sehingga mendapatkan satu kesimpulan ilmiah jawaban atas pertanyaan penelitian ini. Data yang diperoleh diklasifikasikan menjadi data kualitatif selanjutnya diinterpretasikan ke dalam kata-kata atau kalimat-kalimat sehingga diperoleh gambaran yang jelas tentang masalah yang diteliti (Junaidi, 2019). 


\section{HASIL DAN PEMBAHASAN}

\section{Pelatihan Dan Pengembangan}

1. Perencanaan program pelatihan dan pengembangan tenaga pendidik dan kependidikan Madrasah Bertaraf Internasional Amanatul Ummah Pacet, Mojokerto.

Perencanaan SDM menurut Siagian adalah langkah-langkah tertentu yang diambil oleh manajemen guna menjamin bahwa bagi organisasi tersedia tenaga kerja yang tepat untuk menduduki berbagai kedudukan, jabatan, dan kerja yang tepat pada waktu yang tepat. Kesemuanya itu dalam rangka mencapai tujuan dan berbagai sasaran yang telah dan akan ditetapkan (Sinambela, 2016). Strategi perencanaan program pelatihan dan pengembangan oleh Koordinator MBI dapat di paparkan sebagai berikut:

a. Idiom sebagai prinsip yang mendasari. Faktor pertimbangan dalam perencanaan kebutuhan pelatihan dan pengembangan adalah keberadaan guruguru yang berkompeten dan memiliki komitmen yang tinggi terhadap lembaga, yang diterjemahkan di dalam sebuah idiom "jadilah guru yang baik atau tidak sama sekali".

b. Manajemen partisipatoris. yakni memberikan kewenangan dalam membantu pelaksanaan program yang dirancang kepada bawahannya. Seperti teori yang dikemukakan T.Hani bahwa wewenang dapat di perbandingkan dengan sistem syaraf dalam tubuh manusia. Tanpa otak dan syaraf, tubuh manusia tidak dapat berfungsi. Tanpa suatu sistem wewenang, suatu organisasi juga tidak dapat berfungsi (Handoko, 2012).

c. MGMP (Musyawarah Guru Mata Pelajaran). Keberadaan MGMP Internal diharapkan memberikan masukan, saran, evaluasi ke guru serta memberikan masukkan kepada Koordinator dan Wakor dalam setiap perencanaan program yang butuhkan.

d. Pelatihan secara Internal dan Eksternal. Untuk pelatihan dan pengembangan yang sifatnya kedalam dengan mengundang para pembicara, sedangkan untuk pelatihan yang sifatnya keluar dengan mengirimkan delegasi.

2. Proses program pelatihan dan pengembangan tenaga pendidik dan kependidikan Madrasah Bertaraf Internasional Amanatul Ummah Pacet, Mojokerto.

Lijan Poltak Sinambela berdasarkan modifikasi beliau dari Randal S. Schuler, Susan E. Jackson bahwa enam langkah yang ditempuh dalam proses pelatihan: pertama adalah penilaian kebutuhan pelatihan. Kedua memastikan kesiapan organisasi terhadap pelatihan. Ketiga mengkondisikan lingkungan belajar. Empat memastikan pelaksanaan pelatihan. Lima memilih metode pelatihan. Keenam mengevaluasi program-program pelatihan (Sinambela, 2016). Dapat peneliti paparkan sebagai berikut:

1. Penilaian Kebutuhan. Koordinator MBI sendiri tidak merepotkan guru-guru dengan urusan administrasi, tetapi lebih ke pendekatan persuasif. Bapak Koordinator lebih mengajak mereka untuk berdiskusi, sharing, sekaligus upaya membangun kebersamaan. Serta mendapatkan Informasi dari tim MGMP. Selain itu, informasi juga di dapatkan dari Rapat Kerja Tahunan, dalam raker inilah akan di identifikasi arah dan tujuan pelatihan yang 
disesuaikan dengan misi, dasar serta tujuan MBI Amanatu Ummah. Selanjutya, kemudian disepakati baik jadwal, pemateri/instruktur, materi pelatihan, dan seterusnya.

2. Memberikan Dorongan Semangat dan Keyakinan. Koordinator MBI menanamkan keyakinan kepada guru dan pegawai untuk total dalam mengurus dan mendidik anak didik, karena keberadaan mereka bukan saja dari orang tua akan tetapi titipan dari Allah SWT. Sehingga keseriusan mengurus mereka tentu Allah SWT pun akan turut membantu mewujudkan keberadaan masa depan para guru dan anak kandungnya di masa yang akan datang. Serta menanamkan visi, misi dan tujuan dalam setiap pertemuan sehinga hal itu tertanam selalu di jiwa para dewan guru dan pegawai.

3. Mengkondisikan lingkungan pembelajaran. Yakni dengan identifikasi program sehinga pelatihan yang diikuti oleh para guru dan pegawai sesuai tujuan lembaga dan kebutuhan pengembangan jangka panjang pegawai. Serta mempersiapkan bagi para guru dan pegawai mengenai kebutuhan penunjang, baik untuk pelatihan dan pengembangan dengan tersedianya prasana laptop dan wifi.

4. Memastikan pelaksanaan pelatihan. Wakor. Keguruan bertindak sebagai pelaksana proses kegiatannya, di bantu pihak kurikulum yang mempersiapkan keperluannya, seperti memilih narasumber, buku, siapa delegasi dan sebagainya.

5. Memilih metode pelatihan. Pegawai baru di libatkan raker tahunan, di sana secara otomatis mereka akan memahami kerja dan tanggungjawabnya. Jadi, keberadaan tenaga pegawai baru akan terlibat langsung dalam suasana rapat rutin tahunan. Pelatihan tersebut, sebagaimana yang diungkapkan Malayu S.P Hasibuan, menggunakan metode latihan/training classroom methods, yakni metode pertemuan dalam kelas meliputi lecture (pengajaran), conference (rapat), progammed instruction, metode stadi kasus, role playing, metode diskusi, dan metode seminar (Hasibuan, 2018).

Di awal-awal, di adakan pelatihan teaching untuk guru baru karena itu pelatihan dasar, yang menjadi narasumber dalam pelatihan tersebut, di isi oleh guru-guru senior secara bergantian. Sebagaimana dijelaskan Malayu S.P Hasibuan dalam teorinya, bahwa metode pertemua lecture (pengajaran) yakni metode yang diberikan kepada peserta yang banyak di dalam kelas, pelatih mengajarkan teori-teori yang diperlukan sedangkan yang dilatih mencatatnya serta mempersepsikannya (Hasibuan, 2018). Lembaga juga mengadakan pelatihan untuk penerapan pembelajaran k-13. Sedangkan untuk pelatihan bedah SKL, di isi tutor-tutor yang berkompeten, seperti di datangkan langsung dari Diknas Prov. Jatim. Metode tersebut selaras dalam teori Malayu S.P Hasibuan tentang demontration and example adalah metode latihan yang dilakukan dengan cara peragaan dan penjelasan bagaimana cara-cara mengerjakan sesuatu pekerjaan melaui contoh-contoh atau percobaan yang didemonstrasikan (Hasibuan, 2018).

Untuk guru-guru pada tataran manajemen akan di adakan rotasi jabatan. Selain untuk meningkatkan pengetahuan juga agar terampil dalam setiap bidang. Selaras dengan teori yang disampaikan Malayu S.P Hasibuan 
bahwa teknik pengembangan yang dilakukan dengan cara memindahkan peserta dari suatu jabatan ke jabatan lain secara periodik untuk menambah keahlian dan kecakapannya dalam setiap jabatan. Dengan demikian ia dapat mengetahui dan menyelesaikan pekerjaan pada setiap bagian. Jika ia dipromosikan, ia telah mempunyai pengetahuan luas terhadap semua bagian pada perusahaan bersangkutan, sehingga tidak canggung dalam kepemimpinannya (Hasibuan, 2018).

Upaya pengembangan lain yang ada di MBI Amanatul Ummah ini yakni adanya tim MGMP dan tim Olimpiade guru, yang di bawahi langsung oleh Wakor. Guru \& Kepegawaian dan kegiatan workshop. Berdasarkan kegiatan-kegiatan tersebut, metode yang di gunakan dapat dikategorikan menggunakan metode classroom methods. Classroom methods, sebagaimana yang diungkapkan Malayu S.P Hasibuan yakni metode pertemuan dalam kelas yang meliputi lecture (pengajaran), conference (rapat), progammed instruction, metode stadi kasus, role playing, metode diskusi, dan metode seminar (Hasibuan, 2018).

6. Mengevaluasi program pelatihan. Koordinator MBI selaku pimpinan, menemui guru di saat jam istirahat mereka agar pertemuan tidak terkesan formal, namun dalam suasana yang akrab, santai, sehingga obrolan lebih terbuka. Hal lain, beliau secara mendadak/incident melakukan pengawasan. Misalkan mengecek langsung ke kelas dan lain sebagainya. Bagian evaluasi yang lain semacam kuesioner yang disiapkan untuk anak-anak mengisinya. Tindak lanjut dari hasil kuesioner, akan di bawah pada rapat bulan dewan guru. Dan dari berbagai evalusi tersebut, kelanjutannya Koordinator MBI terlebih dahulu melalui pendekatan persuasif, selanjutnya Jika tidak mengalami perubahan, maka akan ada teguran, setelah mendapat teguran tidak menunjukkan perubahan, maka terpaksa guru bersangkutan harus di non-aktifkan. Selaras dengan teori yang disampaikan Marilyn Manning \& Patricia Haddock berikut, Anda harus mengikuti prosedur khusus untuk menangani karyawan dengan kinerja lemah. Selain harus menjadi manajer yang bisa memberi teladan, ada juga beberapa pertimbangan hukum. Langkah-langkah berikut ini perlu diambil ketika kinerja seorang pegawai tidak memuaskan: 1) pelatihan, 2) peringatan verbal, 3) peringatan tertulis, 4) percobaan, 5) pemberhentian (Manning \& Haddock, 2010).

Lijan Poltak Sinambela, dalam teorinya mengatakan, kinerja yang di evaluasi akan memperlihatkan hasil yang efektif atau tidak dan harus diberikan umpan balik. Kinerja yang baik perlu memperoleh apresiasi, sedangkan yang kurang baik perlu dicari penyebabnya. Untuk itu, dibutuhkan kan diagnosis kerja pegawai yang bersangkutan. Proses pemecahan masalah dan komunikasi digunakan untuk mengidentifikasi penyebab dasar dari permasalahan atau kegagalan kinerja, bagi perseorangan, suatu bagian, atau bahkan keseluruhan organisasi (Sinambela, 2016). Apresiasi yang diberikan dalam bentuk hadiah-hadiah yang berbentuk tropi, bingkisan, maupun berupa uang pembinaan dan studi eksklusif ke luar negeri. 
3. Hasil program pelatihan dan pengembangan tenaga pendidik dan kependidikan Madrasah Bertaraf Internasional Amanatul Ummah Pacet, Mojokerto.

Hasil yang di peroleh dari pelatihan dan pengembangan tenaga pendidik dan kependidikan MBI Amanatul Ummah Pacet, Mojokerto. Dapat di terangkan sebagai berikut:

1. Transfers of knowledge.

Guru di tuntut meningkatkan kemampuan mereka dan benar-benar bisa dipraktikkan, menstransfer ilmu pengetahuan itu ke anak didik sehingga dapat menciptakan pembelajaran yang menyenangkan bagi anak didik. Sebagaimana dalam teori yang dijelaskan oleh Syaiful Bahri Djamarah, bahwa dalam proses interaksi belajar mengajar guru adalah orang yang memberikan pelajaran dan siswa adalah orang yang menerima pelajaran. Dalam mentransfer pengetahuan kepada siswa diperlukan pengetahuan atau kecakapan atau keterampilan sebagai guru. Tanpa ini semua tidak mungkin proses interaksi belajar mengajar dapat berjalan secara kondusif. Disinilah kompetensi dalam arti kemampuan mutlak diperlukan guru dalam melaksanakan tugasnya sebagai pendidik (Djamarah, 2012).

2. Prestasi.

Untuk guru, secara prestasi memang para guru belum ada yang di raih. Namun lembaga memfasilitasi dan memberikan dukungan untuk itu. Disisi lain, prestasi mereka dapat di nilai dan di hargai dengan membimbing anakanak didik meraih prestasi setiap lomba yang mereka ikuti. Jadi, prestasi guru dapat di lihat dari jasa yang mereka berikan ke anak didik.

Sedangkan untuk anak didi itu sendiri, keebrhasilan mereka berkat bimbingan dan kompetensi gurunya dibuktikan dengan prestasi-prestasi berikut: Seperti di tahun 2019-2020 ini saja. Berbagai cabang lomba yang anakanak didik menangkan, ada cabang lomba Taekwondo Championship, LKTI, Ilimpiade, PORSENI, POSPEDA, Lomba Debat, Festival Banjari, Lomba Pidato Bahasa Inggris serta Jepang, Cerdas Cermat, National Accounting Rally Competition, Kompetisi Jurnalis, MQK, Festival Paduan Suara, Natinla English Festival, Lomba Baca Puisi, Kompetisi Perkpalan, Lomba Poster, Lomba Imathon, Medspin, Lomba Penulisan Surat, Pencak Silat, Penulisan Essay, Lomba Videography, Lomba Desain Maskot Pornika, Lomba Catur, serta Lomba LKBB Pornika. Sedangkan untuk prestasi yang lain, banyak lulusanlulusan dari MBI Amanatul Ummah yang di terima di berbagai Universitas maupun Institut Unggulan, baik di dalam maupun luar negeri. Dari tahun 2009 sampai tahun 2019 jumlah lulusan yang di terima di berbagai Universitas dan Institut Unggulan berjumlah 2095 siswa/i. Untuk ditahun 2019 saja berjumlah 281 siswa/i, dengan berbagai jurusan yang mereka pilih, baik di bidang profesi, pendidikan, bisnis, dan lain sebagainya.

4. Faktor-faktor yang menjadi pendukung dan penghambat dalam penerapan program pelatihan dan pengembangan tenaga pendidik dan kependidikan Madrasah Bertaraf Internasional Amanatul Ummah Pacet, Mojokerto.

Pendukung. Program pelatihan dan pengembangan itu merupakan bagian upaya dalam mewujudkan visi-misi lembaga, dimana muaranya adalah anak-anak 
didik yang unggul dalam kemampuannya, berakhlaq al-karimah dalam kepribadian. Keberadaan guru-guru di MBI Amanatul Ummah, yang selalu menginginkan penambahan pengalaman serta ilmu-ilmu baru yang bisa diterapkan pada saat proses pembelajaran di kelas. sehingga mendorong lembaga untuk memfasilitasi dan memberi dukungan. Begitu juga dalam rangka pengembangan, lembaga memberikan kesempatan pada guru untuk melanjutkan studi mereka ke jenjang yang lebih tinggi.

Penghambat. Setiap kegiatan tentu akan diiringi dengan kendala-kendala yang bisa memperlambat proses berjalannya sebuah kegiatan. Kendala utama program pelatihan dan pengembangan guru ini, yakni mencari waktu yang tepat, mengingat para guru sudah dibebani tanggungjawab dengan jam mengajar yang penuh, kalaupun dipaksakan untuk ikut karena bersifat penting maka wakor. Kurikulum akan mencari guru penggantinya. karena di MBI Amanatul Ummah sangat tidak mentoleransi keberadaan ruang kelas yang kosong tanpa aktivitas belajar. Kondisi lainnya, dimana lembaga harus memberikan kesempatan libur pada guru sedangkan di waktu bersamaan ada kegiatan pelatihan penting yang harus mereka ikuti. Apabila kegiatan pelatihan dan pengembangan bersifat penting maka Koordinator MBI akan bermusyawarah terlebih dahulu, karena seharusnya libur guru tidak di ganggu dengan kegiatan formal. Hal ini sesuai dengan apa yang dikatakan Mulyasa bahwa dalam menciptakan budaya dan iklim kerja kondusif, kepala sekolah hendaknya memperhatikan prinsip-prinsip: a) guru lebih giat bekerja jika kegiatan yang dilakukan menyenangkan dan menarik, b) tujuan kegiatan sekolah perlu disusun dengan jelas dan diinformasikan kepada guru sehingga mereka mengetahui tujuan bekerja, c) guru harus selalu diberitahu setiap pekerjaannya, d) memberikan hadiah lebih baik daripada hukuman, tetapi hukuman diperlukan sewaktu-waktu, e) usahakan untuk memenuhi kebutuhan sosio-psiko-fisik guru sehingga tercapai kepuasan (Wijaya, 2017).

\section{Kepribadian Guru}

1. Perencanaan dalam program manajemen pribadi guru Madrasah Bertaraf Internasional Amanatul Ummah Pacet, Mojokerto.

Dapat dijelaskan bahwa, ada empat kegiatan yang harus dilakukan oleh perencanaan SDM, yaitu: 1) menginventarisasi persediaan SDM, 2) memprediksi SDM, 3) penyusunan rencana-rencana SDM, 4) memonitor dan evaluasi (Sutrisno, 2009). Dari Koordinator MBI sendiri, perencanaan yang dilakukan melalui beberapa cara berikut:

1. Pembahasan raker tahunan. Kepribadian guru merupakan juga topik yang di bahas pada saat raker tahunan, untuk terus di evaluasi guna disempurnakan. Zakiyah Daradjat menulis faktor terpenting bagi seorang guru adalah kepribadiannya. Kepribadian itulah yang akan menentukan apakah ia bisa menjadi pendidik yang baik bagi anak didiknya atau justru ia menjadi perusak atau bahkan penghancur anak didiknya. Anak didik merupakan generasi penerus, terutama mereka yang masih duduk di sekolah dasar dan menengah, yang masih atau sedang mengalami kegoncangan jiwa (Rochman \& Gunawan, 2016). 
2. Materi seleksi guru. Penilai terhadap kepribadian guru ini sudah mulai terseleksikan dan mendapat pengawalan ketat pada saat proses rekrutmen guru. Faktor utama yang disoroti berkenaan dengan ideologis, bisa dikatakan faktor penentu bagi calon guru yang ingin mengabdi di MBI Amanatul Ummah, walaupun faktor lain memenuhi jika faktor ini tidak terpenuhi, maka secara otomatis akan di backlist, tidak lolos seleksi.

3. Menciptakan budaya kerja. Bapak Koordinator berusaha membangun kebersamaan dengan menciptakan budaya partnership. Dengan tidak pernah menempatkan posisinya di atas akan tetapi beliau selalu menempatkan posisi dimana beliau dengan yang lainnya sama-sama mengabdi, sebagai partner berjuang. Apa yang dilakukan Bapak Koordinator tersebut selaras dengan pendapat Kotter dan Haskett, bahwa proses pembentukkan budaya organisasi mencakup: 1) manajer puncak, 2) perilaku organisasi, 3) hasil, 4) budaya (Saefullah, 2014).

4. Membangun iklim. Prinsip yang di bangun Koordinator MBI bahwa guru itu 'pelayan'. MBI dalam hal ini, berupaya memenuhi harapan wali murid dan anak didiknya, dengan menciptakan iklim yang dimana guru hanya lah seorang pelayan untuk tuannya, untuk melayani mereka dengan sebaikbaiknya.

Sedangkan untuk guru itu sendiri dalam manajemen kepribadiannya dapat dipaparkan sebagai berikut:

1. Lingkungan lembaga. Lingkungan pesantren menjadi faktor pertama yang memberikan pengaruh positifi guru MBI Amanatul Ummah dalam membentuk kepribadiannya. Hal itu didapatkan dari teladan sesama rekan kerja maupun anak didik.

2. Motivasi dari luar. Dorongan motivasi ini didapatkan dari Pengasuh Yayasan Amanatul Ummah, serta keberadaan Koordinator MBI yang selalu stand by setiap harinya guna mengontrol, mengecek serta memastikan aktivitas lembaga berjalan dengan baik. Misalkan pada saat rapat mingguan fungsionaris-manajemen, rapat bulanan guru, bahkan setiap hari-hari tertentu secara tiba-tiba bergabung dengan guru sambil ngobrol dan berdiskusi santai ketika sarapan di pagi hari.

\section{Langkah-langkah yang di lakukan dalam memanajemen kepribadian guru Madrasah Bertaraf Internasional Amanatul Ummah Pacet, Mojokerto.}

Keberhasilan anak didik di MBI Amanatul Ummah dalam meraih prestasi, tidak terlepas dari peran dan teladan Koordinator MBI dan para guru di sana. Upaya manajemen yang Koordinator MBI lakukan yakni:

1. Menyeleksi Pribadi Guru. Saat proses rekrutmen guru baru, penilaian kepribadian seorang guru di seleksi pada saat dilakukan proses interview. Serta uji microteaching untuk mengetahui keilmuan dan cara mengajar yang baik.

2. Mengadakan 'Seminar' Inspiratif. Pada rapat kerja tahunnya, mendatangkan motivator nasional guna memberikan motivasi dan inspirasi kepada guruguru. Robert A. Baron dalam Mangkunegara mengatakan bahwa motivasi merupakan energi yang membangkitkan dorongan dalam diri (drive arousal). 
Dengan demikian, motivasi adalah kondisi yang dapat menggerakkan pegawai agar mampu mencapai tujuan sesuai dengan kebutuhannya (Saefullah, 2014).

3. Etika Menggunakan Handphone. Koordinator MBI menanamkan prinsip kepribadian melalui hal yang sederhana menggunakan hp. Prinsip untuk selalu di pegang para guru di MBI Amanatul Ummah, yaitu “jika ingin dihargai maka juga harus menghargai orang lain" karena akan ngefeknya ke anak didik. Jadi tidak ada guru di dalam forum rapat terus sibuk sendiri dengan aktivitas yang lainnya.

4. Membangun rasa percaya diri. Koordinator MBI selalu menaruh kepercayaan penuh terhadap tugas-tugas yang dipegang oleh masing-masing wakor, guru bahkan kepada anak- anak didik. Hal ini dilakukan untuk membangun kepribadian mereka agar memiliki rasa percaya diri yang tinggi dalam menjalankan amanah yang diberikan.

5. Menjalin Komunikasi yang Baik. Koordinator MBI selalu memantau keadaan para guru 24 jam, untuk mengatahui bagaimana keadaan KBM dan juga keadaan para guru, termasuk hubungan di antara mereka. Beliau akan membuka komunikasi apabila terlihat ada hal yang mengganjal mengenai keakraban sesama guru. Sebagaiman menurut Chester Bernard, dalam teori yang disampaikan Saefullah, bahwa organisasi hanya dapat berlangsung melalui kerja sama antar manusia, dan kerjasama adalah sarana yang memadukan kemampuan individu untuk mencapai tujuan bersama atau tujuan yang lebih tinggi (Saefullah, 2014).

6. Memulai Dari Diri Sendiri. Sikap dan perbuatan Koordinator MBI bener-benar menjadi teladan. Misalkan beliau secara spontan berinisiatif sendiri untuk memindahkan sepatu para guru yang kehujanan di teras kantor Madrasah dan menaruhnya ke tempat yang teduh agar tidak terlalu basah. Keteladanan lain misalkan, pada saat rapat beliau selalu ontime, walau tidak ada orang lain di ruangan tersebut.

7. Menghargai Waktu. Dalam memajemen kedisplinan, Koordinator MBI mengabsen kedatangan dan kepulangan guru dengan menggunakan ceklok (scanner). Bahkan untuk kedisplinan ini, beliau sampe menghitung permenitnya dari kegiatan dauroh untuk anak kelas 12. Karena jika terjadi ketelatan walau hanya 5 menit, akan merugikan waktu belajar kelas lain.

8. Berjiwa Sosial Tinggi. MBI Amanatul Ummah sangat menjunjung tinggi norma sosial, baik itu di dalam maupun di luar lembaga. Untuk tenaga pegawai lebih memberdayakan orang di sekitar lembaga. seperti bagian satpam, tukang kebersihan, tukang masak.

Sedangkan untuk manajemen pribadinya. Ada beberapa hal yang Guru terapkan, seperti:

1. Memahami kompetensinya. Jadi, dapat dikatakan guru yang baik itu terlebih dahulu dapat memahami kompetensinya, khusus mengenai kompetensi kepribadiannya sebagai seorang pengajar dan pendidik. Karena mereka selalu bersama anak-anak 24 jam. Oleh karena itu, guru-guru selalu berupaya memperbaiki kekurangan agar keberadaannya benar-benar diinginkan oleh anak didik sebagai figur teladan. Berkenaan akan tanggung jawab besar guru 
tersebut, Chaerul Rochman \& Heri Gunawan dalam teorinya menerangkan, guru yang memiliki rasa tanggung jawab yang tinggi akan merasa bertanggungjawab atas materi pembelajaran yang disampaikanya kepada siswa sesuai dengan kurikulum, masuk tepat waktu, menjalankan tugasnya dengan sebaik-baiknya, selalu berusaha meningkatkan kompetensi dan kecakapan, serta berusaha mengembangkan keterampilan siswa dan menilai hasil belajar siswa (Rochman \& Gunawan, 2016).

2. Menjaga wibawanya. Di MBI Amanatul Ummah ini lingkungan pesantren. Dulu beberapa guru jilbab masih pendek dan menggunakan pakaian yang ketat. Agar wibawanya terjaga, perlahan dari segi penampilan mulai di perbaiki kekurangannya. Akhirnya mendapat respon baik dari anak didiknya, atas perubahan tersebut. Ini membuktikan bahwa betul, anak-anak akan memperhatikan bapak/Ibu gurunya dari segi penampilan juga. Selanjutnya, seorang guru meski bisa mengontrol cerita, ucapan di depan anak-anak. Karena kalau lose maka anak-anak juga akan merasa tidak ada batasan ke gurunya, malah jadi tidak di hormati. Batasan yang di maksud seperti ada waktunya kita serius, ada waktunya kita itu dekat dan bercanda dengan mereka.

3. Teguran yang instruktif. Jika guru melihat langsung anak didik yang bersikap kurang sopan, berprilaku tidak baik dan sebagainya, di berikan teguran langsung di tempat dengan pendekatan yang instruktif, dengan memberikan pemahaman kesalahan yang mereka perbuat, dan menanamkan rasa tanggungjawab terhadap perilaku tersebut.

4. Siswa sumber inspirasi. Para guru di MBI Amantul Ummah terkadang belajar dari sikap dan perilaku anak-anak yang terlihat. mereka diajarkan agar tidak bersikap acuh dan egois tapi harus peduli dan membantu teman-temannya yang mengalami kesulitan belajar. Dan mereka juga ditanamkan keyakinan yang kuat terhadap pertolongan Allah Ta'ala melalui do'a-do'a yang dipanjatkan.

5. Bijak menegur teman kerja. Tindakan yang di ambil ketika menilai guru lain salah dalam perbuatan dan sebagainya, di diskusikan ke rekan kerja atau secara langsung meminta para senior atau atasan untuk mengambil tindakan, karena yang lebih tau dengan keadaan dan kepribadian guru tersebut. Jika terasa perlu maka akan dibawa ke forum musyawarah dengan atasan. Jika perlu untuk menegur secara langsung, tetap di lakukan dengan sopan, dengan melihat moment yang tepat agar pembicaraan di terima.

6. Saling memberi dorongan pertolongan. Menghargai, menolong, menghormati satu sama lain menjadi sebuah keharusan, karena sistem yang di bangun di MBI Amantul Ummah seperti itu. Bukan untuk saling menjatuhkankan tapi saling mendukung dan memberi dorongan. Jadi, fokus dan total terhadap tanggungjawab yang di amanah. Akan tetapi, jika guru lain membutuhkan maka wajib yang lain memberikan pertolongan.

7. Menjalin hubungan baik kepada atasan. Permasalahan apapun yang terjadi harus selalu di komunikasikan dengan atasan. Staff, guru harus berkoordinasi dengan Wakor atau Koordinator apabila menemukan kendala terhadap tugasnya. Dalam menjalin hubungan baik ini, Syaifurahman \& Tri Ujiati 
menjelaskan, bahwa bisa jadi Anda akan menjadi anak buah favorit kepala sekolah baru dengan melakukan beberapa cara sebagi berikut: 1) Rajin membantu, 2) fleksibel, 3) selalu siap sedia, 4) sabar, 5) perhatikan cara dan gayanya (Syaifurrahman \& Ujiati, 2013).

8. Terus berbenah diri. Evaluasi diri guru banyak di dapatkan dari rekan kerja baik secara sengaja maupun tidak sengaja, terkadang itu terjadi dalam obrolan-obrolan santai serta ketika rapat-rapat terjadi. Misal bagian staff kesiswaan maka sering mendapatkan evalusi itu dari tim kesiswaan, dn seterusnya. Misalkan lagi ketika guru mengalami kesulitan, ragu atas sikap yang telah dilakukan, maka akan berkaca ke rekan kerja yang lain, karena kebetulan tugasnya sama. Begitupun anak didik di lingkungan MBI juga turut memberikan evaluasi pribadi guru itu sendiri. Syaifurahman \& Tri Ujiati dalam teorinya menjelaskan bahwa salah satu tanda guru produktif itu 'bersosialisasi dengan rekan kerja', penting bagi Anda untuk menyediakan waktu bergaul dengan rekan kerja Anda, "bekerja itu harus menyenangkan". Dan itu memang benar sampai batas tertentu. Tentu saja penting bagi Anda menjadi orang yang positif, banyak teman, sering menjadi tempat curhat, sering diminta pendapat, dan sering di ajak berdiskusi. Tetapi Anda tidak boleh larut dalam kegiatan bersosialisasi, tuga Anda adalah bekerja selama jam kerja Anda (Syaifurrahman \& Ujiati, 2013).

\section{Faktor-faktor yang menjadi pendukung dan penghambat dalam memanajemen kepribadian guru Madrasah Bertaraf Internasional Amanatul Ummah Pacet, Mojokerto.}

Adapun yang menjadi faktor pendukung dan penghambat dari manajemen yang di terapkan:

a. Pendukung. Lingkungan MBI Amanatul Ummah ini sangatlah menentramkan. Baik aktivitas belajarnya begitupun suasana religius menghiasi keadaan di sana. Memulai pagi dengan kegiatan istighosah di kelas dan di depan kantor MBI dengan menggunakan TOA. Lingkungan yang seperti ini akan membuat nyaman bekerja dan akan sangat membantu membentuk kepribadian seseorang guru. Seperti keterangan M. Ngalim Purwanto dalam teorinya, bahwa sifat-sifat dan watak kita adalah hasil interaksi antara pembawaan-keturunan dan lingkungan kita. Interaksi antara seseorang dengan lingkungannya itulah yang akan menentukan bagaimana hasil perkembangan aspek-aspek tertentu dalam diri manusia yang selanjutnya akan menetukan bagaimana sifat, watak, dan kepribadiannya (Purwanto, 2014). Di MBI, sangat mengupayakan kedisiplinan. Misalkan: ketika jadwal rapat sudah di tentukan waktunya, maka para guruguru akan berupaya hadir di ruangan tepat waktu. Dengan budaya seperti ini, guru akan merasa malu dengan rekan kerja yang lain seandainya tidak berupaya memperbaiki diri juga untuk tepat waktu. seperti yang dijelaskan Chaerul Rochman \& Heri Gunawan, untuk membiasakan tata kehidupan disiplin, kita bisa memulainya dengan menaati hal-hal yang kecil dan sederhana terlebih dahulu, kemudian hal-hal yang besar dan kompleks. Namun, untuk membiasakan sikap ini seorang guru dituntut bersikap konsisten, pantang menyerah, sabar, ulet, dan Tangguh (Rochman \& Gunawan, 
2016). Disisi lainnya, Motivasi yang diberikan ketua yayasan sebagai upaya agar tetap terjaga semangat para guru dalam menjalankan tanggung jawabnya. Sebagaimana teori yang dijelaskan U. Saefullah, bahwa perubahan yang hendak dilakukan oleh manusia melalui manajemen diri tentu harus didorong oleh motivasi yang kuat. Artinya, kinerja manusia dalam meraih kesuksesan dengan kerja maksimal, harus terus dimotivasi agar tidak berhenti sebelum tujuan tercapai. Oleh karena itu, motivasi kerja dapat diartikan sebagai kondisi yang membangkitkan, mengarahkan, serta memelihara perilaku perilaku berhubungan langsung dengan lingkungan kerja (Saefullah, 2014).

b. Penghambat. Dengan faktor genentik maka secara otomatis keprian seseorang akan ikut keturunan. Tentu ini akan sangat menghambat, tetapi dengan sistem baik yang ada di MBI di harapkan dapat membangun kesadaran dan kemauan yang kuat bagi seorang guru untuk memperbaiki kepribadiannya. Berkenaan dengan ini, sebagaimana diterangkan M. Ngalim Purwanto dalam teorinya, bahwa adapun yang termasuk pembawaan perseorangan yang dalam pertumbuhannya lebih ditentukan oleh pembawaan keturunan antara lain ialah: 1) konstitusi tubuh, 2) cara bekerjanya alat-alat indera, 3) sifat-sifat ingatan dan kesanggupan belajar, 4) tipe perhatian, intelejensi kosiein (IQ), dan tipe intelejensi, 5) cara-cara berlangsungnya emosi yang khas, 6) tempo dan ritme perkembangan (Purwanto, 2014). Begitupun kejenuhan yang muncul dari dalam diri guru tentu akan menghambat juga proses perbaikan diri, karena terlalu padat dan ketatnya jadwal mengajar dan rangkap jabatan.

\section{Hasil dari penerapan program memanajemen kepribadian guru Madrasah Bertaraf Internasional Amanatul Ummah Pacet, Mojokerto.}

Kepribadian adalah unsur yang cukup menentukan ke-akraban hubungan guru dengan anak didik. Kepribadian guru akan tercermin dalam sikap dan perbuatannya dalam membinan dan membimbing anak didik (Djamarah, 2012). Berikut ini beberapa penjelasan tentang guru MBI Amanatul Ummah di mata anakanak didiknya. sebagai berikut:

1. Membantu Dalam Belajar. Secara kesuluruhan para guru di MBI sangat membantu dalam belajar. Dipersilahkan bertanya ketika anak didik kurang memahami. Para guru sangat memberikan keluasan bertanya, bahkan tidak berhenti sampe di dalam kelas saja, ketika mereka berada di luar kelaspun sangat terbuka untuk melayani anak didik. Bahkan apa saja boleh untuk di tanyakan, termasuk itu masalah pribadi. Tidak ada rasa mengeluh dalam diri para guru melayani dengan sangat baik. Sebelum guru mengajar di kelas, guru harus menguasai bahan-bahan apa yang akan disampaikan dan bahan-bahan apa sebagai pendukung proses interaksi belajar. Menurut Sardiman A.M dalam penguasaan bahan pelajaran ada dua macam, yakni "menguasai bahan bidang studi dalam kurikulum sekolah dan menguasai bahan pengayaan/penunjang bidang studi (Djamarah, 2012).

Dalam hal lain, guru sering mengajak diskusi anak, topik bahasan bukan saja masalah pelajaran tetapi juga hal-hal luas yang berkembang juga di bahas dan di kaitkan juga ke pelajaran, ini tentu sangat membantu anak didik mengingat anak didik di larang untuk menggunakan Handphone dan Internet 
yang tersedia kecuali hanya untuk keperluan KBM. Guru yang bersikap seperti ini akan sangat disenangi anak didiknya, sebagaimana yang diungkapkan Syaiful Bahri Djamarah berikut, bahwa guru yang dapat mengerti tentang kesulitan anak didiknya dalam hal belajar dan kesulitan lainnya di luar masalah belajar dan bisa menghambat aktivitas belajar anak didiknya, maka guru akan disenangi anak didiknya (Djamarah, 2012).

2. Teladan Yang Baik. Kepribadian guru di MBI sangat bersahabat dengan anakanak. Siap menerima keluh kesah anak, apalagi perihal yang menyangkut pelajaran. Bahkan kapanpun, siap menfasilitasi, memberikan bantuan ke anakanak jika mereka butuh pertolongan. Begitupun beliau akan langsung membenari jika anak salah dalam hal apapun. Guru sangat menginspirasi, mereka total dalam mendidik. Bahkan waktu untuk keluarga di rumah sering di korbankan demi anak didik di MBI. Dengan keteladanan seperti ini akan mempengaruhi anak-anak untuk mempersembahkan yang terbaik untuk membalas jasa gurunya tersebut. Kepribadian lain yakni kedisiplinan para guru. Di mulai dari kedisplinan mereka masuk kelas untuk mengajar. Termasuk juga kegigihan mereka dalam memecahkan persoalan pembelajaran yang belum terjawab.

Sikap yang ditunjukkan guru-guru di atas, selaras dengan teori yang disampaikan Oemar Hamalik, bahwa sejumlah percobaan dan hasil-hasil observasi menguatkan kaenyataan bahwa banyak sekali yang dipelajari oleh siswa dari gurunya. Para siswa menyerap sikap-sikap gurunya, merefleksikan perasaan-perasaannya, menyerap keyakinan-keyakinannya, meniru tingkah lakunya, dan mengutip pernyataan-pernyataannya. Pengalaman menunjukkan bahwa masalah-masalah seperti motivasi, disiplin, tingkah laku sosial, prestasi dan hasrat belajar yang terus menerus itu semuanya bersumber dari kepribadian guru (Hamalik, 2010).

\section{KESIMPULAN}

MBI Amantul Ummah dalam struktur kepengurusannya di pimpin oleh seorang Koordinator yang memegang kendali setiap kegiatan dan keputusan dalam programprogram yang dijalankan. Untuk program tenaga pendidik dan kependidikan dalam pelaksaan dibantu secara khusus oleh wakil koordinator bidang guru dan kepegawaian yang berkoordinasi dengan wakil koordinator bidang kurikulum.

Strategi manajemen yang diterapkan Koordinator MBI dalam meningkatkan kompetensi tenaga pendidik dan kependidikannya telah di rencanakan secara terprogram, yang mengacu pada visi, misi, dasar pendirian dan tujuan lembaga. Terprogram dengan melalui tahapan-tahapan manajemen yang dilakukan melalui perencanaan, proses, hasil, dan faktor-faktor yang mempengaruhinya.

Manajemen yang diterapkan kepala Koordinator MBI sudah sejalan dengan teori-teori yang ada. Bahkan dalam pelaksanaannya terdapat strategi-strategi yang baru sebagai upaya untuk meningkatkan produktivitas para pegawainya, baik itu sumber daya pendidik maupun tenaga kependidikan. Pada tahap perencanaan dan proses pelaksanaannya sudah sangat dirumuskan dengan baik namun belum terlalu memberikan perhatian maksimal untuk metode mangajar guru dikelas, lebih kepada 
pengembangan masing-masing pribadi guru. Begitu juga yang terjadi pada program peningkatan kepribadian guru. Jadi tidak hanya pemaksimalan pada keberhasilan anak didik akan tetapi juga pemaksimalan atas peningkatan kompetensi keilmuan dan pribadi para guru. Hal ini juga diharapkan memacu semangat tenaga pendidik dan kependidikan untuk membantu mewujudkan apa yang hendak di capai lembaga.

\section{REFERENSI}

Djamarah, Syaiful Bahri. (2012). Prestasi Belajar Dan Kompetensi Guru. Surabaya: Usaha Nasional

Dokumen. (2019). “Presensi Guru TP 2019-2020”. Di akses 22 Januari 2020 pukul 14.41 WIB.

Dokumen. (2019). "Struktur Organisasi Madrasah Bertaraf Internasional (MBI) Amanatul Ummah Pacet Mojokerto". Tanggal 22 September

Dokumen. (2020). “Daftar Lulusan MBI Amanatul Ummah, Tahun Lulusan 2009-2019”. Tanggal 30 Januari

Dokumen. (2020). “Daftar Prestasi Santri MBI Amanatul Ummah Semester 1 Th. 20192020". Tanggal 28 Januari 2020.

Hamalik, Oemar. (2010). Psikologi Belajar Mengajar. Bandung: Sinar Baru Algesindo

Handoko, T. Hani. (2012). Manajemen Edisi Kedua. Yogyakarta: BPFE-Yogyakarta

Hasibuan S.P, Malayu. (2018). Manajemen Sumber Daya Manusia. Jakarta: Bumi Aksara

Junaidi, Heri. (2019). Metode dan Praktek Penelitian dengan Strategi Temukenali. Palembang: Noer Fikri

Kartiko, Ari. (2019). Manajemen Mutu Pendidikan. Yogyakarta: Bening Pustaka

Manning, Marilyn \& Haddock, Patricia. (2010). Manajemen Kantor, Panduan Produktivitas dan Efektivitas Edisi Revisi. Jakarta: PT. Indeks

Purwanto, M. Ngalim. (2014). Ilmu Pendidikan Teoritis Dan Praktis. Bandung: Remaja Rosdakarya

Rochman, Chaerul \& Gunawan, Heri. (2016). Pengembangan Kompetensi Kepribadian Guru. Bandung: Penerbit Nuansa

Saefullah. (2014). Manajemen Pendidikan Islam. Bandung: CV. Pustaka Setia

Sinambela, Lijan Poltak. (2016). Manajemen Sumber Daya Manusia. Jakarta: Bumi Aksara

Sugiyono. (2011). Metode Penelitian Kuantitatif Kualitatif dan REBB. Bandung: Alfabeta

Sutrisno, Edy. (2009). Manajemen Sumber Daya Manusia. Penerbit: KENCANA

Syaifurrahman, dan Ujiati, Tri. (2013). Manajemen Dalam Pembelajaran. Jakarta Barat: PT Indeks

Tanzeh, Ahmad. (2011). Metodologi Penelitian Praktis. Yogyakarta: Teras

Wijaya, David. (2017). Manajemen Pendidikan Kontemporer. Yogyakarta: Pustaka Belajar

Yunus, Syarif. (2018). Guru atau Kurikulum; Titik Urgen Kualitas Pendidikan Indonesia. Dalam https://kumparan.com/syarif-yunus/guru-atau-kurikulum-titik-urgenkualitas-pendidikan-indonesia. Diakses 2 Mei 2018 